УДК 325.15+94(477)"1929/1931"

DOI 10/15421/312008

Т. Л. Кудрицька

Дніпропетровський начіональний історичний музей

імені Д. І. Яворничького

\title{
РАДЯНСЬКІ ШВЕДИ В ПОШУКАХ КРАЩОГО ЖИТТЯ: МІЖ ШВЕЦІЕЮ ТА СРСР
}

Кудрицька Т. Л. Радянські шведи в пошуках кращого життя: між Швецією та СРСР.

У статті проаналізовано нетривалий період проживання радянських шведів поза межами СРСР - у Швеції. Розкрито кілька точок зору на приїзд діаспори з боку представників шведського суспільства, наведено заходи, вжиті шведським урядом, для облаштування переселенців. Охарактеризовано причини невдалої адаптації тастини старошведів у метрополії, а також досліджено реакцію радянської пропаганди на повернення емігрантів. Зроблено висновок про світоглядні зміни, які відбулися у свідомості деяких представників діаспори, завадивши їм адаптуватися до шведського капіталістичного суспільства.

Ключові слова: старошведи, емігранти, Швеція, СРСР, адаптація, рееміграція.

Кудрицкая Т. Л. Советские шведы в поисках лучшей жизни: между Швецией и СССР.

В статье проанализирован непродолжительный период проживания советских шведов за пределами СССР - в Швеции. Раскрыто несколько точек зрения на приезд диаспоры со стороны представителей шведского общества, приведены меры, принятые шведским правительством для обустройства переселенцев. Охарактеризованы причины неудачной адаптации части старошведов в метрополии, а также исследована реакция советской пропаганды на возвращение эмигрантов. Сделан вывод о мировоззренческих изменениgx, которые произошли в сознании некоторых представителей диаспоры и помешали им адаптироваться в шведском капиталистическом обществе.

Ключевые слова: старошведы, эмигранты, Швеция, СССР, адаптация, реэмиграция.

Kudrytska T. L. Sowjetische Schweden auf der Suche nach einem besseren Leben: zwischen Schweden und der UdSSR.

Der Artikel analysiert die kurze Aufenthaltsdauer sowjetischer Schweden außerhalb der UdSSR in Schweden. Es werden verschiedene Ansichten zur Ankunft der Diaspora durch Vertreter der schwedischen Gesellschaft vorgestellt und die Maßnahmen der schwedischen Regierung zur Unterbringung von Vertriebenen vorgestellt. Die Gründe für die erfolglose Anpassung einiger alter Schweden in der Metropole werden charakterisiert und die Reaktion der sowjetischen Propaganda auf die Rückkehr von Auswanderern untersucht. Die Schlussfolgerung wird über die Veränderungen der Weltanschauung gezogen, die im Bewusstsein eines Teils der Diaspora stattgefunden haben. Diese Veränderungen verhinderten, dass sie Teil der schwedischen kapitalistischen Gesellschaft wurden.

Schlüsselwörter: Alte Schweden, Auswanderer, Schweden, UdSSR, Anpassung, Wiederauswanderung.

Kudritska T. L. The Soviet Swedes in a search of a better life: between Sweden and the USSR.

The article analyzes the short period of the Soviet Swedes living outside the USSR in Sweden (while their reemigration). It is proved that majority of the native Swedes saw the common roots with the Soviet Swedes diaspora, approved their reunion and admired their ability to preserve national identity for a long period (about two hundred years) of living outside Sweden. Their arrival in the Motherland was called as reunification. However, there was also a different opinion among the native Swedish society. Some parts of the Swedes were criticising the Swedish government for the financial support of the resettlement. In the context of the economic crisis in the country, the Soviet Swedes were considered as a labor force. The Swedish government set up a committee to take care of the migrants' adaptation. The committee planned to connect the Soviet Swedes to successful farmers so that they could get business experience. The settlers were reported that all the money, having spent on their settlement, was only a government loan that they would have to repay. The mismatch between the expectations and the reality, the new conditions and requirements (loans and interest rates, capitalist competition and a new type of society) they faced, gave rise to the Soviet Swedes' desire to seek an even better fate. The last one they traditionally associated with relocation and emigration. Under the influence of the communist propaganda, some poor Swedes decided to return

(C) Т. Л. Кудрицька, 2020 
to the USSR. Changing their plans for future, they considered their departure to Sweden as a reckless step and proclaimed the Soviet Union their only true homeland. The back return of 265 Swedes (33\% of the diaspora) to the USSR proved that the mentality of the Ukrainian Swedish immigrants had been changed by the Bolsheviks power and national policy. It turned out that the paternalistic policy of the state during the Russian Empire and the uninitiated life during the Soviet era (when the Swedes realized that nothing depended on them) did make some of them a kind of «other» people. This thing changed them so much that they were ready to be satisfied with small possibilities. That is why they were unable to take risks, could not live under the condition of competitive society and capitalist market.

Key words: Old Swedes, emigrants, Sweden, USSR, adaptation, re-emigration.

Шведи - одна 3 наймалочисельніших за кількістю серед сучасних національних меншин України (налічує близько двох десятків осіб), представники якої з'явилися на теренах Північного Причорномор'я у 1782 р., утворивши шведське поселення - с. Старошведське (Gammalsvenskby). Незважаючи на нечисленність, шведське населення не «розчинилося» i не «загубилося» серед інших національних меншин протягом імперського періоду історії. За радянських часів пाведи неодноразово напряму взаємодіяли 3 радянськими урядами УСРР / УРСР та СРСР, були предметом для міжнародних перемовин між СРСР та Швецією й служили прикладом у звітах статистики, де проголошувався всеосяжний радянський вплив (утворення національної сільради, шкільна освіта та колгоспний рух).

Разом 3 тим саме радянський етап в історії шведської національної меншини вивчений зовсім мало, порівняно із іiі життям за царської епохи. Окремими науковцями було розпочато дослідження долі шведського населення у часи Української революції та в роки Другої світової війни, розкрито сюжети еміграції шведів до Швеції у 1929 р., приділено увагу сталінському експерименту стосовно перебудови ідентичності пведського населення України та політичним репресіям серед шведського населення в 1930-х pp. [1; 4 -6]. Практично недослідженим залишається період перебування старошведів у Швеції у 1929-1931 рр. Його вивчення допоможе пояснити причини повернення частини представників пшведської національної меншини зі Швеції до СРСР та виявити зміни в ментальності старошведів, які завадили їм стати частиною суспільства IIIвепіiі. Залучивши публікації шведської та радянської преси, які відображали еміграційні процеси в середовищі радянських шведів у 1929-1930$\mathrm{x}$ pp., звернемо увагу на прийом емігрантів у метрополії, наведемо різні точки зору в суспільстві IIIвепіії на приїзд переселенців, охарактеризуємо діяльність радянської пропаганди стосовно повернення старошведів до CPCP.
Нестабільність господарського i політичного життя, волюнтаристська політика радянського уряду стосовно релігії та приватної власності викликали невдоволення шведського населення України. Продовольча допомога, яку старошведам надавала метрополія - IIIвеція в умовах голоду 19211923 рр. та у 1928 р., підтримка освітнього процесу та сприяння релігійному життю діаспори демонстрували патерналістське ставлення метрополії й викликали бажання шведів емігрувати до «Матері-Svea». Вони змогли використати гасла радянської влади щодо права на національне самовизначення в СРСР та протистояти натиску антиеміграційної пропаганди уряду на свою користь. 22 липня 1929 р. майже всі представники шведської національної меншини України у кількості 888 осіб виїхали із СРСР.

Здавалося, що еміграція продемонструвала переважну безуспішність спроб радянізації шведської національної меншини України та довела неефективність політики коренізації, принаймні щодо невеликої за складом етнічної групи старошведів. Проте подальші події змусили засумніватись у категоричності цього висновку.

1 серпня 1929 р. старошведи прибули на південь Швеції до м. Трелеборг. Емігрантів зустрічав натовп людей на чолі з принцом Карлом, який вітав їх від імені населення країни та виражав надію на їхне щасливе життя на рідній землі $[11$, р. 68, 74; 17, p. 60]. Від імені емігрантів виступив учитель Г. П. Утас, який подякував за допомогу у возз'сднанні 3 «Матір'ю-Svea» після розлуки тривалістю 147 років [15].

Урядом Швеції було створено комітет у справах переселенщів «Gammalsvenskbykommitten», головою якого призначив себе принц Карл. Його членами були генерал Г. Мальм, голова округи К. Дальберг, командуючий Енестрем та держсекретар Хаммершельд. Завданням комітету був збір коштів на придбання ферм для поселення емігрантів, а також на їхне навчання місцевому способу ведення господарства [21]. У той час шведів тимчасово розмістили в таборі в м. Йончепінг. 
Приїзд діаспори набув висвітлення у пресі. Лейтмотивом публікацій тогочасної преси, присвяченої емігрантам, став пошук спільних рис зі старошведами. Наприклад, у цьому дусі написано статтю Г. Квіста, надруковану в газеті «Trelleborg» у 1929 р. Автор фокусувався на фізичній спорідненості населення Швеції зі старошведами, ставив у приклад співвітчизникам доброчинність, релігійність та працьовитість переселенців [18]. У газеті «Helsingborgs Dagblad» було надруковано вірш шведського поета А. Беренкрейца, де він висловлював сподівання, що «брати та сестри» будуть вірою служити Швеції та шанувати іiі [12].

Однак не всі представники суспільства радо зустріли емігрантів, у яких вбачали конкурентів у боротьбі за робочі місця. Один із старошведів (А. Аннас) нарікав на дискримінацію, яка існувала у шведському суспільстві стосовно його односельців [11, p. 22]. Причиною цього, скоріше за все, були фінансові витрати уряду на переїзд та облаштування переселенців, а також їх працевлаштування, що в умовах економічної кризи в країні викликало невдоволення окремих шведських підданих. Змінити думку скептично налаштованої частини шведського суспільства намагалася журналістка А. Елгстрьом. У своїй статті, яку надрукували в «Almanack för alla» y 1930 p., авторка торкалася питання трудової конкуренції, наголошуючи на сільськогосподарській спеціалізації емігрантів та наявності вільних робочих місць у цій галузі державного господарства [15].

Приїзд старошведів висвітлювався не лише у Швеції. Публіцистика шведських емігрантів у Канаді (газети «Svenska Canada-Tidningen» 1 «Canada Posten») у 1929 р. присвятила емігрантам низку публікацій, у яких їхнє повернення до Швеції подавалося як реалізація природного бажання возз'еднатися зі свосю нацією. При цьому підкреслювалися взірцеві риси ментальності старошведів - чесність, скромність, релігійність, працьовитість. Канадські пведи захоплювалися тим, чого бракувало їм самим: збереженням старошведами елементів своєї національної ідентичності всупереч «тривалій русифікації, онімеченню та радянізаціі» [19].

Після приїзду переселенці зіткнулися з проблемами акліматизації та адаптації. Півиічний клімат Скандинавії став для вихідпів 3 Південної України неочікуваним «сюрпризом» $[20$, р. 6]. Скоріпा за все, зимовий одяг, який вони носили в Україні, виявився недостатньо презентативним і теплим для зими у Швеції. Місцеве населення намагалося забезпечити старошведів теплими речами [15].
Для успішної господарської адаптації переселенців планувалося розселити на о-ві Готланд та в районі Вастерготланд, що поблизу численних фермерських господарств. За розрахунками влади це мало дозволити емігрантам перейняти господарський досвід щонайменше за 2 роки [14]. План розселення родин загрожував роз'єднати монолітну до того спільноту. Комітет планував фінансувати купівлю власних господарств для тих шведів, які отримають найкращі відгуки від їхиіх наставників та доведуть можливість керувати фермою [21]. Комітет попередив, що фінансування буде мати характер держпозики 3 процентами. Влада виключала постійну підтримку старошведів, сподіваючись на їхню швидку адаптацію [14].

Невідповідність між очікуваннями i реальністю, нові умови та вимоги (позики та проценти, капіталістична конкуренція), 3 якими вони зіштовхнулися, породили у старошведів бажання пошуку ще кращої долі, що традиційно пов'язувалося ними 3 переїздом. У фокусі їхньої уваги з'явилася нова країна потенційної еміграції - Канада. Ще 17 серпня 1929 р. у Швеції стало відомо, що Шведська лютеранська асоціація допомоги в Канаді в особі пастора Вірена запропонувала старошведам профінансувати переселення до Північної Америки. Для цього було зібрано 150 тис. дол. Частина старошведів відгукнулася на запрошення. За свідченнями Е. Гоас, 60 родин планували виїхати до Канади [13].

Проте, як не дивно, інша частина емігрантів побажала повернутися до СРСР. Незважаючи на фінансування переселення до Канади, скоріш за все, частина шведів боялася нових невдалих спроб пошуку благополучного життя. До того ж і на території ШШвеції відбувалася пропаганда місцевих комуністів. Комуністична партія Швеції створила «Робочий комітет у справах шведського поселення» (Arbetarnas Svenskbykommitté), який діяв на противагу «Gammalsvenskbykommitten» і займався контрпропагандою серед емігрантів [5, c. 81]. Напевно, представникам комітету - В. Нільссону, К. Густафссону, Х. Фрідрекссону та іншим вдалося те, у чому раніше зазнала поразки радянська влада. Користуючись об'єктивними обставинами, вони змогли внести розлад у монолітну до цього групу емігрантів, налаштувати частину незаможних шпведів проти ініціатора переїзду старошведів iз СРСР - пастора Хр. Гоаса. Iх переконали, що пастор влаштував еміграцію з метою примусити бідних старошведів працювати на багатіїв у північній країні. Ймовірно, така 
пропаганда була успішною через те, що частина шведів була дезорієнтована різницею в економічному устрої СРСР і Швеції, адже в капіталістичній країні кожен відповідав сам за себе. Колишні мешканці СРСР звикли до дій тільки за наказами «згори». Тому ті шведи, які не змогли протидіяти викликам капіталістичного світу, стали сприятливим матеріалом для агітації Комуністичної партії Швеції щодо повернення назад до УСРР.

Від імені прорадянськи налаштованої групи шведів (20 осіб) колишній голова шведської національної сільради УСРР П. Кнутас разом з В. Утасом, I. Утасом, А. Утасом та Е. Кнутасом 16 листопада 1929 р. надіслали листа до Центральної комісії у справах національних меншостей при ВУЦВК УСРР. Вони просили дозволу повернутися до СРСР, який тепер називали «радянською батьківщиною». Свій виїзд до Швеції чоловіки вважали необміркованим кроком. Переселенці називали себе «радянськими трудівниками» i висловлювали бажання співпрацювати 3 комуністичною владою: «Ми нічого не маємо проти колективізації і обіцяємо підтримувати всі заходи радянської влади». Також вони прохали про надання допомоги в поверненні, отриманні своїх старих домівок та їдоцької норми землі $[4$, с. 131$]$.

Радянська преса називала цей лист «бомбою, що вибухнула», проте друкувала його з певними корективами. Варто зазначити, що редакція не могла визначитись із характеристикою авторів листа. Спочатку в коментарях ix називали заможними середняками та глитаями, а далі по тексту вони поступово ставали жертвами, обдуреними глитайською та попівською агітацією. Наведені пресою уривки 3 листа - здебільшого творчість редакції, далека від правди: «Після неврожаю радянський уряд зробив усе можливе. Ми дістали хліб і картоплю. Держава організувала їальні для школярів. Уряд не вимагав відшкодування витрат... У Швеції вже наполягають на відшкодуванні витрат... Гоас одурив нас, щоб обернути на поміщицьких та глитайських невільників... Ми питаємо, хіба це не кріпацтво? Ми ладні повертатися пішки до України». Наприкінці підсумовувалося, що націоналістичний галас про рятування «братів шведів від більшовицького гніту» зазнав повної поразки [3].

В. Утас і П. Кнутас виступили на зборах Компартії Швеції, на яких розповіли про своє скрутне становище, порівнявши його із їхнім життям в Україні: «Швеція - батьківщина для багатих. У Радянському Союзі трудящим щороку стає жити легше й краще, а в Швеції - гірше й важче. Ми хочемо разом із радянськими робітниками і селянами будувати краще майбутнє для трудящих всього світу» [9].

Наміри частини шведів повернутися до СРСР довели, що ментальність шведівпереселенців з України зазнала змін. Виявилося, що патерналістська політика держави за часів Російської імперії та безініціативне життя в роки радянської влади (коли шведи розуміли, що від них нічого не залежить) таки зробила частину 3 них «іишими» людьми. Ця частина, скоріш за все, втратила працьовитість, була готова задовольнятися малим та нездатна ризикувати, не вміла жити в умовах конкурентної економіки та капіталістичного ринку.

Перемовини з приводу рееміграції велися дипломатичною представницею СРСР О. Коллонтай з головою уряду Швеції К. Екманом та міністром закордонних справ $\Phi$. Рамелем. Справами рееміграції керувало радянське консульство на чолі зі В. Смірновим. Хоча СРСР був зацікавлений у поверненні шведів, шо мало частково реабілітувати його міжнародне реноме і стати уроком для інших бажаючих залишити країну, радянська сторона поводилася на переговорах стримано, що було продуманим кроком та позбавило СРСР витрат на рееміграцію, яку повністю оплатив уряд Швеції. Обов'язковою умовою для повернення реемігрантів була їхня згода вступити до колгоспу [5, с. 87-89].

Старошведи поверталися до УСРР кількома хвилями. 25 грудня 1929 р. із Швеції вирушило 18 реемігрантів. У радянській пресі зазначалося, що вони розчарувалися в «буржуазній батьківщині» i наразі закликають шведських робітників та селян взяти приклад 3 їхніх товаришів у СРСР, що встановили диктатуру пролетаріату [8]. Канадська преса розцінила повернення старошведів до УСРР як зраду. У газеті «Svenska Canada-Tidningen» цих переселенців називали шпигунами [19].

Рееміграції шведської національної меншини було надано міжнародного резонансу. Її представляли як перемогу радянського способу життя над західним буржуазним. Одного з переселенців (В. Утаса) було запрошено на радіоефір до м. Москви для ознайомлення громадськості з життям емігрантів поза межами СРСР. Виступаючи на всю країну, він висловив своє розчарування ставленням до його односельців у Швеції та розповів про незадовільні умови проживання в капіталістичній країні. Виступ адресувався радянським та закордонним слухачам і вівся російською, шведською та німецькою мовами $[17$, р. $61 ; 19]$. Ця радіотрансляція 
стала в пригоді антиеміграційній урядовій пропаганді. Рееміграція пведів подавалася як повчальний приклад для іиших, свідчення того, що в радянсыкій країні були створені найоптимальніші умови проживання $[7$, с. 5 ; 5 , с. 90]. На той час серед менонітського та німецького населення вирували еміграційні настрої: тисячі селян перебували у Москві, чекаючи дозволу на виїзд [2, с. 153].

3 нагоди повернення першої групи шведів було влаштовано святковий вечір у приміщенні колишньої церкви, яку зробили будинком культури. На зібранні публічно засудили пастора Хр. Гоаса, звинувативши в агітаційтій діяльності проти СРСР. Перебування у Швеціӥ порівняли 3 тягарем ярма експлуатації. СРСР, навпаки, називали «справжньою Батьківщиною націй, які раніше були пригноблені» $[10$, с. 2]. Від шведів виступив В. Утас, який визнав, що шведи вчинили величезну помилку: «Ми раніше не вірили заходам радвлади, а були цілком під впливом агігації пастора на грунті релігійного задурманення»). Оратор виголосив «колективне переконання»: «Тільки радянська влада і компартія наші друзі, які бажають нам кращого життя». У підсумку шведи висловили бажання «стати до трудових лав працівників і боротися з агітацією пасторів» $[10$, с. 2]. Радянські пропагандисти переконували читачів, що капіталістичний досвід зробив зі шведів «свідомих радянських громадян», які беруть активну участь у будівництві комунізму.

11 вересня 1930 р. повернулася наступна група шведів у кількості 39 осіб, а 17 серп- ня 1931 р. - остання група реемігрантів (208 осіб). Зауважимо, що це були неповні родини, частина членів яких вирішила залишитись у IIвеції. Зі шведами приїхали діячі комуністичної партіі Швеції К. Густафсон, Е. Блюм, К. Холмстрьом, Е. Петерсон, К. Андерсон, X. Лаунстайн, які бажали залишитися в УСРР та стати новими духовними лідерами $[17$, p. 65]. Отже, із 888 осіб емігрантів повернулося 265 шведів (33 \% представників діаспори).

Таким чином, у 1930-1931 pp. до УСРР повернулася лише частина бідняцького шведського населення, яка не змогла адаптуватися до кліматичних умов й економічного устрою Швеції та стала сприятливим грунтом для комуністичної агітації. Повернення назад до УСРР частини шведів, які за соціальним складом належали до бідняцького населення, свідчить про успішну комуністичну агітацію та певні соціальні й світоглядні зміни, які відбулися у свідомості представників діаспори. Відбувся розрив родин, частина яких вирішила залишитись у метрополії. Це свідчить про ідеологічні розбіжності у середовищі переселенців. Шведи із «заможним» минулим, учителі та пастор Хр. Гоас або залишилися у Швеції, або виїхали до Канади. Повернулася саме та частина емігрантів, яка була згодна жити за радянськими законами. Це свідчило про певні успіхи соціалістичної роботи, а також про невміння цих шведів жити в умовах капіталістичної системи, брати на себе відповідальність та проявляти ініщіативу.

\section{Бібліографічні посилання}

1. Безносов А. Альтшведендорф в годы революции и Гражданской войны: судьбы шведов. Этнические неииы России: исторический феномен «народа в пути»: материалы XII Международной научной конференции (Москва, 18-20 сентября 2008 г.). М., 2009. С. 421-432.

2. Безносов О. Спроба втечі з «раю»: еміграційний рух серед менонітів та німців-колоністів Півдня України наприкінці 20-х рр. XX ст. Вопросы германской истории. Д., 2009. С. 147-156.

3. Жертви глитаївсько-попівської агітації. «Братишведи» на «батьківщині». Bicmi. 1929. 5 грудня. URL: https://prosvita-ks.co.ua/z-istoriyi-zmiyivskih-shvediv/ zhertvi-glitayivsko-popivskoyi-agitaciyi (дата звернення: 12.11.19).

4. Коник Ю. Рееміграція пведського населення Херсонського округу в 1929 р. за документами Державного архіву Херсонської області. Нариси з історії Бериславични. Вип. 4. Херсон - Берислав, 2005. С.132-139.

5. Котлярчук А. «В кузнище Сталина»: шведские колонисты Украины в тоталитарных экспериментах XX века. М., 2012. 221 с.

6. Кудрицька Т. Українські шведи в роки сталінських репресін (1933-1937). Вопросы германской истории. Д., 2013. С. 178-190.
7. Менонітів теж обдурили як i пведів. Наддніпрянська правда. 1930.5 сіння. С. 5 .

8. Назад на радянську Батьківщину. Наддніпрянська Правда. 1929. 31 грудня. URL: https://prosvitaks. co.ua/z-istoriyi-zmiyivskih-shvediv/nazad-na-radyanskubatkivshchinu (дата звернення: 12.11.19).

9. У СРСР трудящим стає жити легше i краще. Наддніпрянська правда. 1929. 6 грудня. URL: https:// prosvita-ks.co.ua/narisi-z-istoriyi-berislavshchini-vipusk-9/ z-istoriyi-zmiyivskih-shvediv (дата звернення: 12.11.19).

10. Юнгштурм. Тільки радянська влада й компартія - наші друзі. Наддніпрянська правда. 1930. 21 січня. C. 2

11. Annas A. 1781-1929. 171 years in a foreign land. Life in the Gammalsvenskby. URL: http://www.svenskbyborna.se/Canadian $\% 20$ site-filer/Andreas $\% 20$ Annas $\% 20$ translation_dec2008.pdf (дата звернення: 12.09.19).

12. Berencreutz A. Dikter. Vid Gammalsvenskbybornas ankomst 1 augusti 1929. Helsingborgs Dagblad. 1929. den 7 aug. [Електронний ресурс]. - Режим доступа: http://www.gammalsvenskby.se/FablerDikter.htm (дата звернення: 12.12.19).

13. Brev Frân Emma Hoas Till Kyrkoherde E. Wirén. Gammalsvenskby-förlāggningen i Jönköping, den 
8 januari 1930. URL: http://www.gammalsvenskby.se/ BrevfrGsby1894.htm (дата звернення: 12.12.19).

14. Brev Frẵn Prins Carls till Svenskbyborna 1929. Avskrift. Stockholın, juli 1929. URL: http://www.gammalsvenskby.se/PrinsCarl1929.htm (дата звернення: 12.12.19).

15. Elgströin A. Gammalsvenskbybornas öden i Fornoch Nutid. Almanack för alla. 1930. URL: http://www. gammalsvenskby.se/OinSvenskbyborna.htm (дата звернення: 12.12.19).

16. Gaunt D. Swedes of Ukraina as "Volksdeutsche" the Experience of World War II. Bопросы германской истории. Д., 2007. Pp. 239-250.

17. Hedman J. Gammalsvenskby. The true story of the Swedish settlement in Ukraine. Stockholm, 2005. 77 s.
18. Qvist P. G. (G. Palmqvist). När sagan blev sanning. Trelleborgs Tidning. 1929. URL: http://www. gammalsvenskby.se/Narsaganblevsanningl.htm (дата звернення: 12.12.19).

19. Rudling A. Ukrainian Swedes in Canada: Gammalsvenskby in the Swedish-Canadian press 1929-1931. Scandinavian-Canadian studies. 2005. Vol. 15. Pp. 62-91. URL: https://scancan.net/rudling_1_15.htm (дата звернення: 14.12.19).

20. Tysk K.-E. Anna Portje berattar om sitt liv. Skara, 2011. $16 \mathrm{~s}$.

21. Weiss Fr. Dokument om Gammalsvenskbyborna. Gammalsvenskby kommittén. Tam-Revy, 2009. URL: http://www.gammalsvenskby.se/ Gammalsvenskbykoinmittn.htm (дата звернення: 12.12.19).

\section{References}

1. Beznosov A. (2009) Al'tshvedendorf v gody revolyutsii $i$ Grazhdanskoy voyny: sud'by shvedov [Altschwedendorf during the Revolution and the Civil War: the fate of the Swedes]. Ethnic Germans of Russia: the historical phenomenon of "people on the way": Proceedings of the XII International Scientific Conference (September 18-20, 2008), pp. 421-432. Moscow (in Russian).

2. Beznosov O. (2009) Sproba vtechi $z$ «rayu»: emihratsiynyy rukh sered menonitiv ta nimtsiv-kolonistiv Pivdnya Ukrayiny naprykintsi 20-kh rr. XX st. [Attempt to escape froin "paradise": the emigration inovement among Mennonites and German colonists in southern Ukraine in the late 20 's of the twentieth century]. The questions of German history, pp. 147-156. Dnipropetrovsk (in Ukrainian).

3. Zhertvy hlytayivs 'ko-popivs'koyi ahitatsiyi. "Bratyshvedy" na "bat'kivshchyni». [Victims of Glitaiv-pop agitation. «Swedish brothers» in the «hoineland»]. Visti. 1929. December 5. Available at: https://prosvita-ks.co.ua/z-istoriyi-zmiyivskih-shvediv/zhertvi-glitayivsko-popivskoyiagitaciyi (accessed: 12.11.19). Kyiv (in Ukrainian).

4. Konyk Y. (2005) Reemihratsiya shveds'koho naselennya Khersons 'koho okruhu v 1929 r. za dokumentamy Derzhavnoho arkhivu Khersons 'koyi oblasti [Re-emigration of the Swedish population of the Kherson district in 1929 according to the documents of the State Archives of the Kherson region]. Essays on the history of Beryslav region, vol. 4, pp.132-139. Kherson (in Ukrainian).

5. Kotlyarchuk A. (2012) «V kuznitse Stalina»: shvedskie kolonisty Ukrainy $v$ totalitarnykh eksperimentakh $X X$ veka ["In Stalin's Forge": Swedish Colonists of Ukraine in the Totalitarian Experiments of the 20th Century]. Moscow (in Russian).

6. Kudryts'ka T. (2013) Ukrayins'ki shvedy $v$ roky stalins 'kykh represiy (1933-1937) [Ukrainian Swedes during the Stalinist repressions (1933-1937)]. The questions of German history, pp. 178-190. Dnipropetrovsk (in Ukrainian).

7. Menonitiv tezh obduryly yak i shvediv [Mennonites were also deceived as well as the Swedes]. Dnieper truth. 1930. January 5, p. 5. Kherson (in Ukrainian).

8. Nazad na radyans' $k u$ Bat'kivshchynu [Back to the Soviet homeland]. Dnieper truth. 1929. Deceinber 31. Available at: https://prosvita-ks.co.ua/z-istoriyi-zmiyivskih-shvediv/nazad-na-radyansku-batkivshchinu (accessed: 12.11.19). Kherson (in Ukrainian).

9. USRSR trudyashchym staye zhyty lehshe $i$ krashche [In the USSR workers are living easier and better] (1929) Dnieper truth, 1929, December 6. Available at: https://pros- vita-ks.co.ua/narisi-z-istoriyi-berislavshchini-vipusk-9/zistoriyi-zmiyivskih-shvediv (accessed: 12.11.19). Kherson (in Ukrainian).

10. Yunhshturm. (1930) Til'ky radyans'ka vlada y kompartiya - nashi druzi [Only the Soviet government and the Communist Party are our friends]. Dnieper truth, January 21, p. 2. Kherson (in Ukrainian).

11. Annas A. 1781-1929. 171 years in a foreign land. Life in the Gammalsvenskby. Available at: http://www. svenskbyborna.se/ Canadian\%20site-filer/Andreas\%20 Annas\%20translation dec2008.pdf (accessed: 12.09.19) (in English).

12. Berencreutz A. (1929) Dikter. Vid Gammalsvenskbybornas ankomst Helsingborgs Dagblad, den 7 aug. Available at: http://www.gammalsvenskby.se/FablerDikter.htm (accessed: 12.12.19) (m Swedish).

13. Brev Frân Emma Hoas Till Kyrkoherde E. Wirén. Gammalsvenskby-förläggningen i Jönköping, den 8 januari 1930. Available at: http://www.gammalsvenskby.se/ Brevfr Gsby1894.htm (accessed: 12.12.19) (in Swedish).

14. Brev Från Prins Carls till Svenskbyborna (1929). Avskrift. Available at: http://www.gammalsvenskby.se/PrinsCarl1929.htm (accessed: 12.12.19). Stockholm (in Swedish).

15. Elgströın A. (1930) Gammalsvenskbybornas öden i Fornoch Nutid. Almanack för alla. Available at: http:// www.gammalsvenskby.se/Om Svenskbyborna.htm (accessed: 12.12.19) (in Swedish).

16. Gaunt D. Swedes of Ukraina as "Volksdeutsche"the Experience of World War II. The questions of German history, pp. 239-250. Dmpropetrovsk (in English).

17. Hedman J. (2005) Gammalsvenskby. The true story of the Swedish settlement in Ukraine. Stockholm (in English).

18. Qvist P. G. (G. Palmqvist) (1929) När sagan blev sanning. Trelleborgs Tidning. Available at: http://www. gammalsvenskby.se/ Narsaganblevsanning1.htm (accessed: 12.12.19). Stockholin (in Swedish).

19. Rudling A. (2005) Ukrainian Swedes in Canada: Gammalsvenskby in the Swedish-Canadian press 1929 1931. Scandinavian-Canadian studies, Vol. 15, pp. 6291. Available at: https://scancan.net/rudling 1 15.htm (accessed: 14.12.19) (in English).

20. Tysk K. (2011) Anna Portje berattar om sitt liv. Skara (in Swedish).

21. Weiss Fr. (2009) Dokument orn Gammalsvenskbyborna. Gammalsvenskby kommittén. Available at: http://www.gammalsvenskby.se/ Gammalsvenskbykommittn.htm (accessed: 12.12.19). Stockholm (in Swedish). 